\title{
High-Affinity Binding and Lack of Growth-Promoting Activity of 12(S)-Hydroxyeicosatetraenoic Acid (12(S)- HETE) in a Human Epidermal Cell Line
}

Eva Gross, Dipl.-Biol., Thomas Ruzicka, M.D., Birgit v. Restorf, Wilhelm Stolz, M.D., and Karl-Norbert Klotk, Ph.D. Department of Dermatology, University of Munich, and Department of Phtrmucology (K-NKG), Univerxity of Heidelberg, Federal Republic of Germany

The arachidonic acid metabolite 12-hydroxyeicosatetrenoic acid (12-HETE) is assumed to play an important role in skin physiology and pathophysiology. Specifically, it has recently been discussed as a growth promoting agent in keratinocytes. Our aim was to find out whether epidermal cells possess specific receptors for 12-HETE which would mediate the effects of this eicosanoid in skin, including the putative growth stimulating activity. We could identify specific binding sites for 12(S)-HETE on the human epidermal cell line SCL-II. The analysis of binding data revealed a single class of binding sites with a $K_{d}$ of $2,6 \mathrm{nM}$ and $2 B_{\max }$ of 216,000 sites per cell. The binding was saturable, readily reversible, and specific for 12(S)-HETE with lower affinities for other monoHETE. We failed to detect any significant proliferative activity of 12(S)-HETE in the same epidermal cell line, although we applied three independent methods for evaluation of cell growth and used a concentration of 12(S)-HETE which should enable an optimal receptor occupancy. Thus, epidermal cells possess high-affinity 12(S)-HETE binding sites which are likely to be involved in the effects of this eicosanoid in epidermis. However, biologic effects other than direct growth stimulation seem to be transduced by 12(S)-HETE receptors in epidermal cells which need further investigation. J Invest Dermatol 94:446-451, 1990
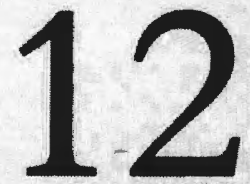

-HETE is a monoarygenated membolite of arachidonic acid produced by the 12-lipoxygenase pathway. It is currently assumed to play an important role in cutaneous biology and in the pathophysiology of inflammatory skin disexses, in particular, psoriasis $[1,2]$. Epidermal cells possess a high capacity for the metabolic transformation of arachidonic acid to 12-HETE. It is the main eicosanoid generated in epidermal tissues of various species besides $\mathrm{PGE}_{2}$ and $P G D_{2}[3,4]$. In addition, highly elevated concentrations of 12-HETE are found in psoriatic skin lesions [5]. This may be of pathogenetic importance in view of the potent chemotactic effects of 12-HETE on leukocytes [6]. The exact functions of 12-HETE in normal and disensed skin, however, are not yet fully understood. Recent observations point to a possible role in wound healing, because 12-HETE is also 2 chemoattractant for fibroblasts, and, as preliminary findings show, for keratinocytes as well $[7,8]$.

Finally, there is good evidence for a role of 12-HETE in epidermal growth promotion. After application of 12-HETB in vivo, 2 significant epidermal hyperproliferation was shown in addition to the inflammatory reaction $[9,10]$. So far, however, it is unclear

Manuscrips received May 17, 1989; accepted for publication November 14. 1989.

This work was partly supported by Deutsche Forschungagemeinschaft (Ru 292/2-3 and Sto 189/1-1).

Reprint requests to: Priv.-Doz. Dr. T. Ruzicka, Department of Dermatology. Univenity of Munich, Frauenlobstrale 9-11, 8000 Munchen 2, West Germany.

Alboreviations:

DMGE: Dalbecco's modified Engle's medium

FCS: fecel cilf eerum

HETE: hydroxycicontetratcnoic acid

SCL-II: squamours cell carcinoma cells whether the hyperprolifention results from a direct growth stimulatory effect of 12-HETE on keratinocytes or represents an indirect effect via infiltrating leukocytes. This uncertainty is due to contradictory results concerning the growth promoting ability of 12 HETE on keratinocytes in cell culture reported in the litetature [11,12].

Our group is investigating the role of 12-HETE in skin with special reference to its physiologic functions in normal skin and its pathophysiologic role in psoriasis and other hyperproliferative and inflammatory dermatoses. Therefore, we addressed the question of whether epidermal cells possess specific receptors for 12-HETE which may be involved in the transduction of its biologic effects in cutaneous tissues. In addition, we tried to resolve the question of the growth-stimulating activity of 12-HETE in receptor-bearing epidermal cells. The elucidation and characterization of such receptors should enable us to further define the role of 12-HETE in skin, and, most importantly, could pave the way for the development of receptor antagonists with potential use in the treatment of psorinsis.

Here we report for the first time the detection and characterization of specific binding sites for 12(5)-HETE on a human epidermal cell line. These putative receptors seem, however, not to mediate 2 direct growth promoting activity because of the lack of growth stimulation by receptor saturating concentrations of 12(S)-HETE.

\section{MATERLALS AND METHODS}

$(5,6,8,9,11,12,14,15-H[N]) 12-S$-HETE, specific activity $225 \mathrm{Cl} /$ mmol, was purchased from New England Nuclear (Dreieich, FRG). 12-S-HETE, 12-R-HETE, and other lipoxygenase products were obtained from Paesel (Frankfurt, FRG). Methyl- ${ }^{-3}$ H-thymidine, specific activity $185 \mathrm{~GB} \mathrm{q} / \mathrm{mmmol}$, was purchased from Amersham (Braunschweig, FRG).

Cell Culture Human squamous cell carcinoma cells (SCL-II), derived from explant culture of a squamous cell cancer [13], were a gift from N.E. Fusenig (German Cancer Research Center, Heidel- 
berg, FRG). Cells were grown in Dulbecco's modified Eagle's medium (DMEM) supplemented with $2 \mathrm{mM}$ glutomine, $100 \mathrm{U} / \mathrm{ml}$ penicillin-streptomycin, and $10 \%$ fetal calf serum (FCS) (Flow Laboratories, Meckenheim, FRG) and incubated at $37^{\circ} \mathrm{C}$ in a humid $5 \% \mathrm{CO}_{2}$ atmosphere. Cultures were routinely split with $0.1 \%$ tryp$\sin / 0.02 \%$ EDTA in PBS without $\mathrm{Ca}^{++}$and $\mathrm{Mg}^{++}$.

Mycoplasma Toating Mycoplasma contamination of SCL-II cells was excluded by using a furorescent dye method [14].

Binding Assays Binding assays were performed in 24-multiwell culture trays (Flow Laboratories, Meckenheim, FRG) with SCL-II cells growing in monoliyers. In 2 standard 2ssay, cultures were washed twice with PBS and incubated with 12(S)-[3H] -HETE in DMEM without FCS buffered with $10 \mathrm{mM}$ Hepes (- incubation buffer) in a final volume of $400 \mu /$ per well. The incubation was performed at $4^{\circ} \mathrm{C}$ under continuous shaking. The binding reaction was terminated after $2 \mathrm{~h}$ by rapidly washing the cells 4 times with ice-cold incubation buffer. After solubilization of the cells with 0.1 $\mathrm{N} \mathrm{NaOH}$ the cell bound radioactivity was measured by liquid scintillation spectrometry. Nonspecific binding was determined in the presence of $1 \mu \mathrm{M}$ unlabeled 12(S)-HETE. Specific binding was defined as the difference of total binding of $12(\mathrm{~S})-\left[{ }^{3} \mathrm{H}\right]-\mathrm{HETE}$ and nonspecific binding.

Time course of binding was determined by incubating SCL-II cells with $0.1 \mathrm{nM} 12(\mathrm{~S})-\left[{ }^{3} \mathrm{H}\right]$-HETE in the presence or absence of an excess of cold 12(S)-HETE for various time intervals. Reversibility of binding was assessed by equilibrating the cells with $0.5 \mathrm{nM}$ $12(\mathrm{~S})-\left[{ }^{3} \mathrm{H}\right]$-HETE. After $90 \mathrm{~min}, 0.5 \mu \mathrm{M}$ unlabeled $12(\mathrm{~S})$-HETE was added to induce dissociation of the radioligand.

For determination of equilibrium binding data, SCL-II cells were incubated with increasing concentrations of $12(\mathrm{~S})-\left[{ }^{3} \mathrm{H}\right]$-HETE. For competition experiments the cell cultures ware incubated with 1 $\mathrm{nM}$ 12(S)-[ $\left.{ }^{3} \mathrm{H}\right]-$ HETE and increasing concentrations of a series of mono- and diHETE.

Saturetion and competition data were analyzed by non-linear curve-fitting with the progmm SCTFIT $[15,16]$.

Growth Avags SCLII cells were plated in 6-well plates (Flow Laboratories, FRG) at a density of 500,000 cells per well in DMEM containing $10 \%$ FCS. After 24 h the culture medium was removed and the cells were exposed to DMEM +0.5\% FCS with or without $10^{-8} \mathrm{M} 12$ (S)-HETE. The medium was changed every third day. Cells grown in medium containing $0.5 \% \mathrm{FCS}$ in the presence of 10 $\mathrm{ng} / \mathrm{ml}$ EGF or cells grown in $10 \%$ FCS served as positive controls. To study possible synergistic effects, experiments wore performed with coincubation of cells with EGF and 12(S)-HETE.

'H-Thymidine-Incorporation After treatment of cells with 12(S)-HETE or growth factors for various time intervals the cell layers were incubated for $4 \mathrm{~h}$ with ${ }^{3} \mathrm{H}$-thymidine $(1 \mu \mathrm{Ci} / \mathrm{ml})$. After washing with PBS, cells were solubilized with $1 \mathrm{ml}$ of $0.1 \mathrm{~N}$ $\mathrm{NaOH}$, and the incorporated radioactivity was measured by liquid scintillation counting. In parallel experiments, cell proliferation was assessed by cell counts.

DNA Cytometry After 24 or $48 \mathrm{~h}$ of treatment with $10^{-6} \mathrm{M}$ 12(S)-HETE or growth factors, SCL-Il cells were trypsinized and centrifuged onto coverslips. The cells were Feulgen-stained according to Böhm [17]. DNA analysis was performed using the high-resolution image analysis system IPS (Kontron, Eching, FRG) as previously described". Brielty, the specimens were digitalized with a density of 16 pirels/um using a TV Pasecon camera (Bosch, Stuttgart, FRG) connected with a 100-oil objective of an Axioplan microscope (Zeiss, Oberkochen, FRG). After automatic segmentation for each nucleus, the optical density (OD) and the ares were calcu-

- Stola W; Vogt T, Braun-Falco O, Abmays W, Bckent F, Kaudewiza P, Vieluf D, Bieber K, Burg G: Difforention between lymphomas and puendolymphomas of the skin by computerized DNA-image cytometry (uibmitted). lated. The integrated optical density (IOD) was obtained by multiplying the $O D$ by the area [18]. In Feulgen-stained nuclei the IOD is linearly correlated with the DNA content [17]. In each slide, 20 chicken erythrocytes were used as an internal reference. According to a previous pilot study, the normal diploid DNA value [19] was calculated by multiplying the mean IOD of erythrocytes with 3.26 . In this study, the relative DNA content of 100 randomly selected cells was measured. As marker for the proliferative activity the mean value of the relative DNA content of the keratinocytes was established.

\section{RESULTS}

Specific Binding of 12(S)-[अH]-HETE to SCL-II Colls Radioligand binding assays were routinely performed at $4^{\circ} \mathrm{C}$ to prevent catabolism and incorporation of 12(S)-HETE into phospholipids [12]. To examine time kinetics of 12(S)-HETE binding, SCL-II cells were incubated with 12/S)-[ ${ }^{3} \mathrm{H}$ ]HETE for varying time intervals. Specific binding of $\left.12(\mathrm{~S})-{ }^{3} \mathrm{H}\right]$ HETE reached equilibrium within $2 \mathrm{~h}$ (Fig 1). For subsequent experiments, a 2 -h incubation was therefore employed. In order to assess reversibility of $12(S)$ HETE binding, a 1000-fold excess of cold 12(S)-HETE was added to cells preincubated for 90 min with 12 (S)-[ $\left.{ }^{3} \mathrm{H}\right]$ HETE. Reversibility of binding was indicated by a rapid drop of cell-associated radioactivity (Fig 2).

The characteristics of the putative receptor such as affinity and number of binding sites per cell were estimated by incubating SCLIl cells with increasing concentrations of $12(\mathrm{~S})-\left[{ }^{3} \mathrm{H}\right]$ HETE between 0.1 and $5 \mathrm{nM}$. The saturation curve in Fig 3 was analyzed assuming a one-site model and gave a $K_{D}$ value of $2.6 \mathrm{nM}$ and $B_{\text {nat }}$ value of 216,000 sites per cell. Nonspecific binding of 12(S)-[ $\left.{ }^{3 H}\right]$ HETE increased as a linear function of the radioligand concentration and amounted to about $50 \%$ of total binding at $\mathrm{K}_{\mathrm{D}}$. Thus, at $12(\mathrm{~S})$ [ ${ }^{3} \mathrm{H}$ ]HETE concentrations higher than $5 \mathrm{nM}$ no reliable radioligand binding could be measured.

A series of lipoxygenase products of arachidonic acid was used in competition experiments. The rank order of potency in competition for $12(\mathrm{~S})-\left[{ }^{3} \mathrm{H}\right]$ HETE was $12(\mathrm{~S})$-HETE $>12(\mathrm{R})$-HETE $>5(\mathrm{~S})$ HETE $>$ LTB $_{4}>15$-HETE (Fig 4). 8,15-di-HETE and arachidonic acid (not shown) were incfiective in concentrations up to 1 $\mu \mathrm{M}$. The affinities of the lipoxysenase-derived elcomnoids are shown as Ki-values in Table I.

\section{Bffect of 12(S)-HIETE on Cell Growth}

H-Thymidine Inconparation: H-thymidinc incorporation into SCL-II cells was measured at various time points in SCL-II cells incubated with 12(S)-HETE or growth factors up to $72 \mathrm{~h}$. 12(S)-

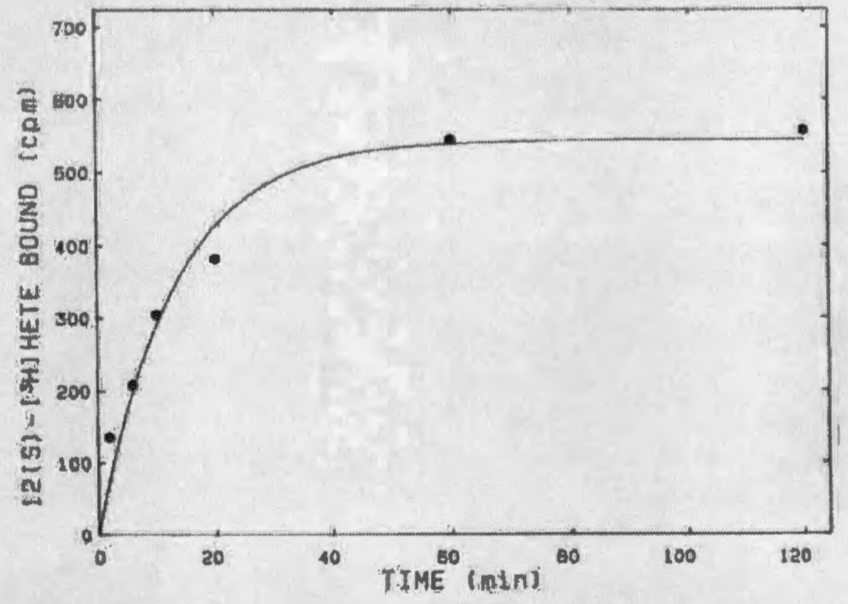

Figure 1. Time course of spacific 12(S)-[PH]HETE binding to SCL-II cells. Cells were incubated in duplicate with $0.1 \mathrm{nM} 12(5)-\left[{ }^{3} \mathrm{H}\right) \mathrm{H}$ HIER at $4^{\circ} \mathrm{C}$ for varibus time intervals. This experiment was represencative of three independent binding assayz. 


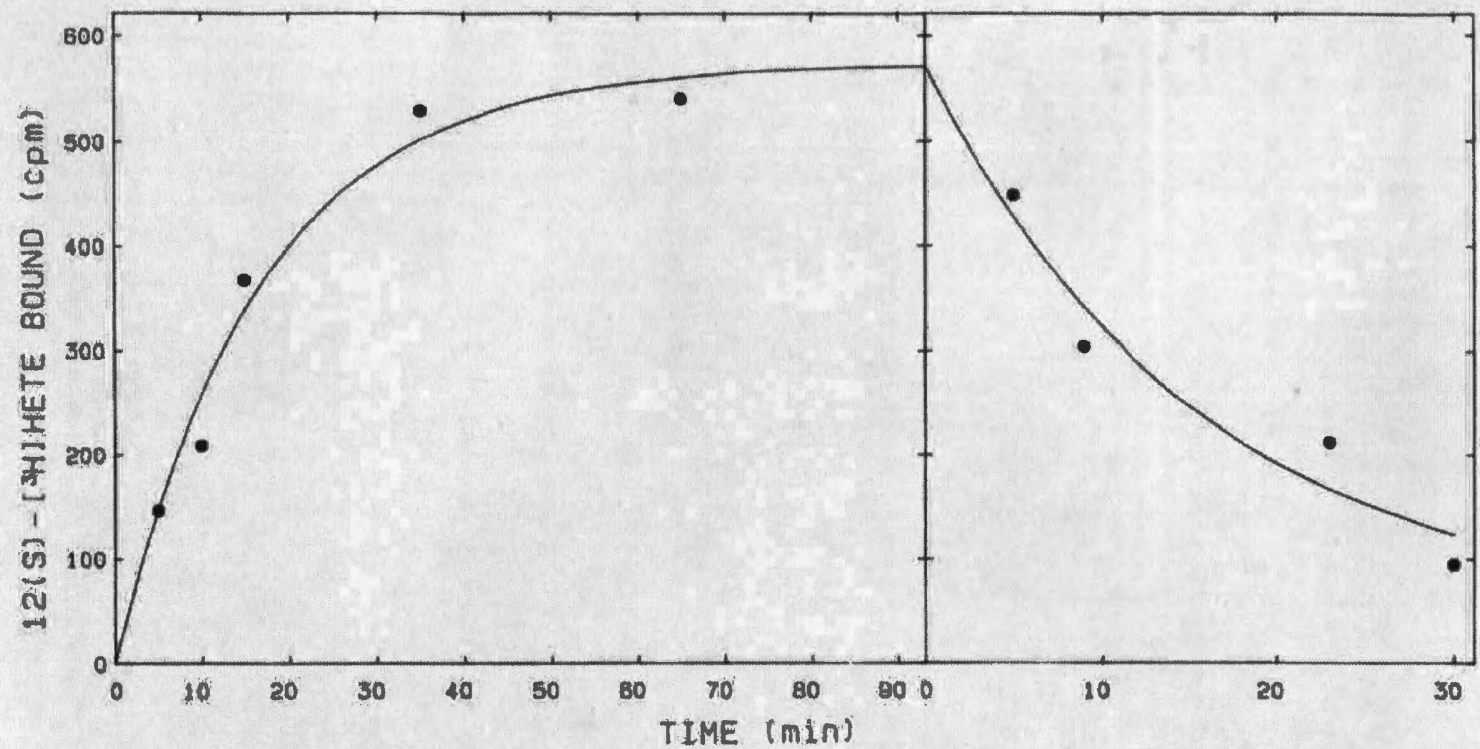

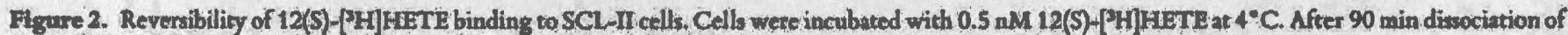
12(S)-[ ${ }^{3} \mathrm{H}$ [HETE was induced by addition of $0.5 \mathrm{MM}$ eold $12(5)$ - HETE. Date points are the mean of duplicate amples.

HETE did not increase ${ }^{3} \mathrm{H}$-thymidine incorporation above levels in untreated cells. In contrast, EGF and medium containing 10\% FCS showed an increase in incorporated thymidine with a maximum at $72 \mathrm{~h}$ of incubation (Fig 5). In a single experiment, incubation of cells with 12-(S)-HETE for $6 \mathrm{~d}$ did not result in growth stimulation.

When cell counts were taken as a measure of cell proliferation, a slight, but negligible increase in cell number was obtained with 12(S)-HETE. The effects of EGF and 10\% FCS on cell growth were significant (Fig 5), 12(S)-HETE had no additive effect on EGF-induced growth stimulation when ased in combination.

Computer-Assisted DNA Cytometry The relative DNA content of Feulgen stained SCL-II-cell nuclei was calculated by the image analysis system IPS. As marker of cell proliferation the mean values of the relative DNA content were estimated. No significant proliferative activity of 12(S)-HETE on SCL-II cells was observed after 24 or 48 h of treatment. In contrest, cells treated with EGF or

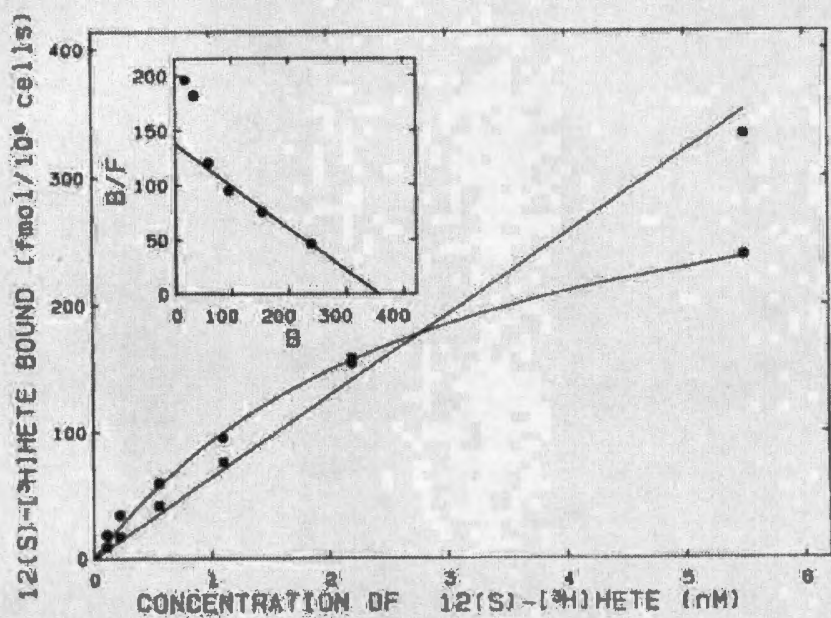

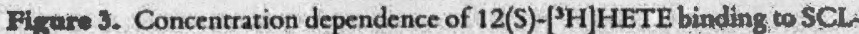
II cells. Cells were incubated for $2 \mathrm{~h}$ as described in Methods. Data are shown as specific (circles) and nonspecific binding (squant). Non-linear curve firting gave a $\mathrm{K}_{\mathrm{D}}$-value of $2.6 \mathrm{nM}$ and a B of 216,000 sites per cell. The inser shows a Scatchard plot of the data. Data points ane the mean of duplicate samples and are representative of three independent experimenta.
10\% FCS showed a significant increase of their nuclear DNA content reflecting a growth-promoting activity (Fig $6 A-F$ ).

\section{DISCUSSION}

Numerous observations point to an important role of the amachidonic acid derivative 12-HETE in cutancous physiology and the pathophysiology of inflammatory and hyperproliferative skin diseases $[1-12]$. The molecular mechanisms whereby 12-HETE influences epidermal functions have; however, not been analyzed so far. In particular, the question of whether 12-HETE exerts its effects on epidermal cells via specific receptors has not been investigated. In addition, there is dispute concerning the growth stimulating activity of 12-HETE on keretinocytes in vitro $[11,12]$, whereas in vivo, an unequivocal growth promotion was observed $[9,10]$. This may, however, be the result of growith fnctors released from leukocytes that were chemoractically attracted in skin by 12 -HETE. We therefore addressed the question of whether epidermal cells poseess spe-

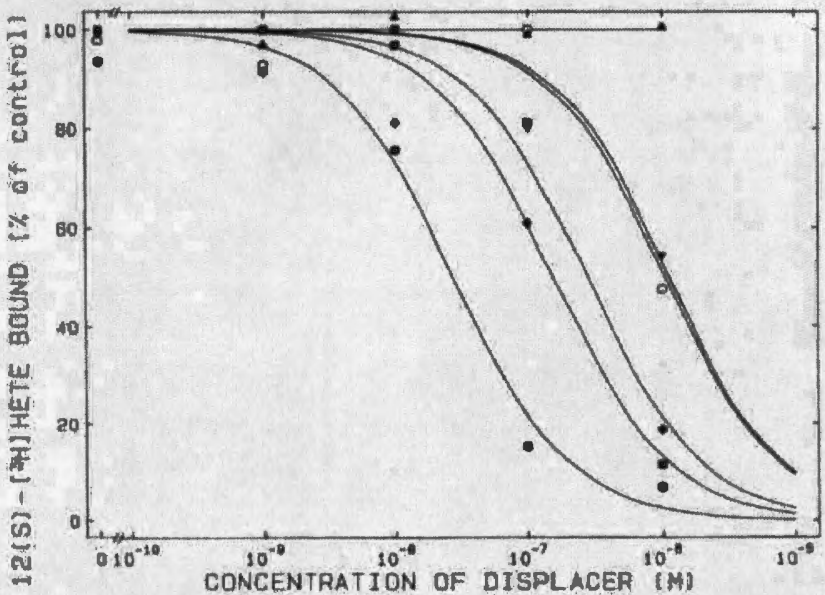

Figure 4. Competicion of several lipoxygenase products for 12(S)[PH]HETE binding. Cells were incubated with I $\mathrm{nM} 12(\mathrm{~S})-{ }^{3} \mathrm{H}$ ]HETE at $4^{\circ} \mathrm{C}$ with increasing concentrations of different compounds. Data are plote ted as percent of epecific $12(\mathrm{~S})-\left[{ }^{3} \mathrm{H}\right]$ HETE binding. This experiment was representative of two independent assays. Circle: 12(S)-HETE; diemond: 12(R)-HETE; square: $5(\mathrm{~S})$-HETE; inverned triangle: LTB $_{4}$; triangle: 8,15 diHETE; open dircle: 15-HETE. 
Table I. Ki-values for the Inhibition of 12(S)-[HH]HETE Binditing by a Saries of Hydroitylated Eicosanioids

\begin{tabular}{|c|c|c|}
\hline & 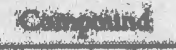 & itofold \\
\hline 7 & $\begin{array}{l}\text { 12(S)-HETE } \\
12(\mathrm{R}) \text {-HETE } \\
\text { 5(S)-HETE } \\
\text { 15(S)-HETE } \\
\text { LTB. }\end{array}$ & $\begin{array}{r}18 \\
100 \\
180 \\
830 \\
700\end{array}$ \\
\hline
\end{tabular}

cific 12-HETE binding sites by using radioligand binding assays. In addition, we tried to resolve the uncertainty about the effects of 12-HETE on cell growth using different methods for the assessment of cell proliferation.

We were able to demonstrate the presence of high-affinity 12 (S)HETE binding sites in the human epidermal cell line SCL-II. The binding showed characteristics of a receptor by exhibiting saturability, reversibility, and specificity for 12(S)-HETE when compared with a series of hydroxylated arachidonic acid products. Further analysis of the binding data disclosed a single binding site with high affinity. 12(R)-HETE was a potent competitor of 12(S)-HETE for the binding site. This may be of special interest because the 12(R)isomer was described as the predominant form of 12-HETE in psoriatic lesions [22]. Thus, the putative effects of $12(\mathrm{R})-\mathrm{HETE}$ in psoriasis may be mediated by the 12 (S)-HETE receptor.

Recently, we also reported on the specific binding of $\mathrm{LTB}_{4}$ to SCL-II cells [22]. Further elucidation of 12-HETE and LTB, binding sites to clarify the question of whether the two ligands bind to a common or distinct structure is necessary. Nevertheless, we believe that 12-HETE is of greater relevance in the pathophysiology of inflammatory skin diseases. Generally, LTB, is considered as a much stronger inflammatory agent than 12-HETE. On the other hand, 12-HETE is present in much higher concentrations in normal and diseased skin and the results of our binding studies showed higher binding affinity of 12-HETE. Finally, in our in vivo system in skin [10], both mediators seemed to be of similar potency.

SCL-Il cells bearing the specific 12(S)-HETE binding sites did not respond with enhanced DNA synthesis when incubated for various time intervals with receptor saturating concentrations of the ligand. In contrast, in medium containing low serum concentrations cells were still responsive to mitogenic stimuli as evidenced by increased DNA synthesis in the presence of BGF and 10\% FCS. Thus, we could not confirm the findings of Kragballe et al [11], who reported a growth stimulation of keratinocytes by 12(S)-HETE. The discrepancies between our results and those of the above authors could be a result of different experimental conditions. First, we used a non-confluent transformed epidermal cell line in contrast to confluent normal human keratinocytes. Second, our cells were grown in medium coneaining $0.5 \%$ FCS in contrast to $15 \%$ FCS. We assume, however, that our experimental design, using very low serum concentrations, is more relevant for detecting the response of cells to possible growt th factors. Besides, DNA analysis was assessed in our studies by three different methods: thymidine incorporation cell counts, and computer-assisted DNA cytometry. The results of Kragballe et al are based on thymidine incorporation only, which is problematic because epidermal cells metabolize thymidine. In addition, our results are consistent with those of Otto et al [12]. These suthots examined the growth-promoting activity of 12(RS)-HETE on notmal human epidermal cells using $0.5 \%$ FCS. The growth assays performed on confluent and non-confluent culcures did not detect trowth stimulation.

Although we cannot exclude the existence of seccond, low-aftinity binding site, the use of higher concentrations of 12-HETE than $10^{-1} \mathrm{M}$ (which would saturate a presumable low affinity site) did not result in a proliferative activity of keratinocytes according to Otto et al. The question of which specific function on epidermal cells if not growth promotion is then mediated by the 12-HETE receptor arises. Our preliminary findings, obtained in cooperation with R. Hein and T. Krieg, rather suggest that the biologic function of 12 (S)-HETE receptors on epidermal cells may be the transduction of chemotactic signals [8]. This would fit into the general concept of lipoxygenase-derived eicosanoids as chemotactic mediators. Taking into consideration also the observed fibroblast chemotactic activity of mono HETE [7], a role in wound healing emerges 25 the possible physiologic function of 12/S)-HETE in 3 kin.

In summary, we report for the first time on the identification and characterization of specific 12(S)-HETE binding sites on epidermal cells. These findings should enable us to further elucidate the role of 12-HETE in cutaneous biology and in the pathophysiology of psoriasis and other inflammatory and hyperproliferative dermatoses. In addition, these findings may lead to the development of receptor antagonists which could serve as experimenal probes and be potentially useful in the pharmacotherapy of psoriasis.

We chank MArs. C. Trautwein-Maller for the excellent assistance and Mrs. B. Dosch

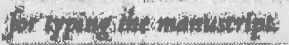
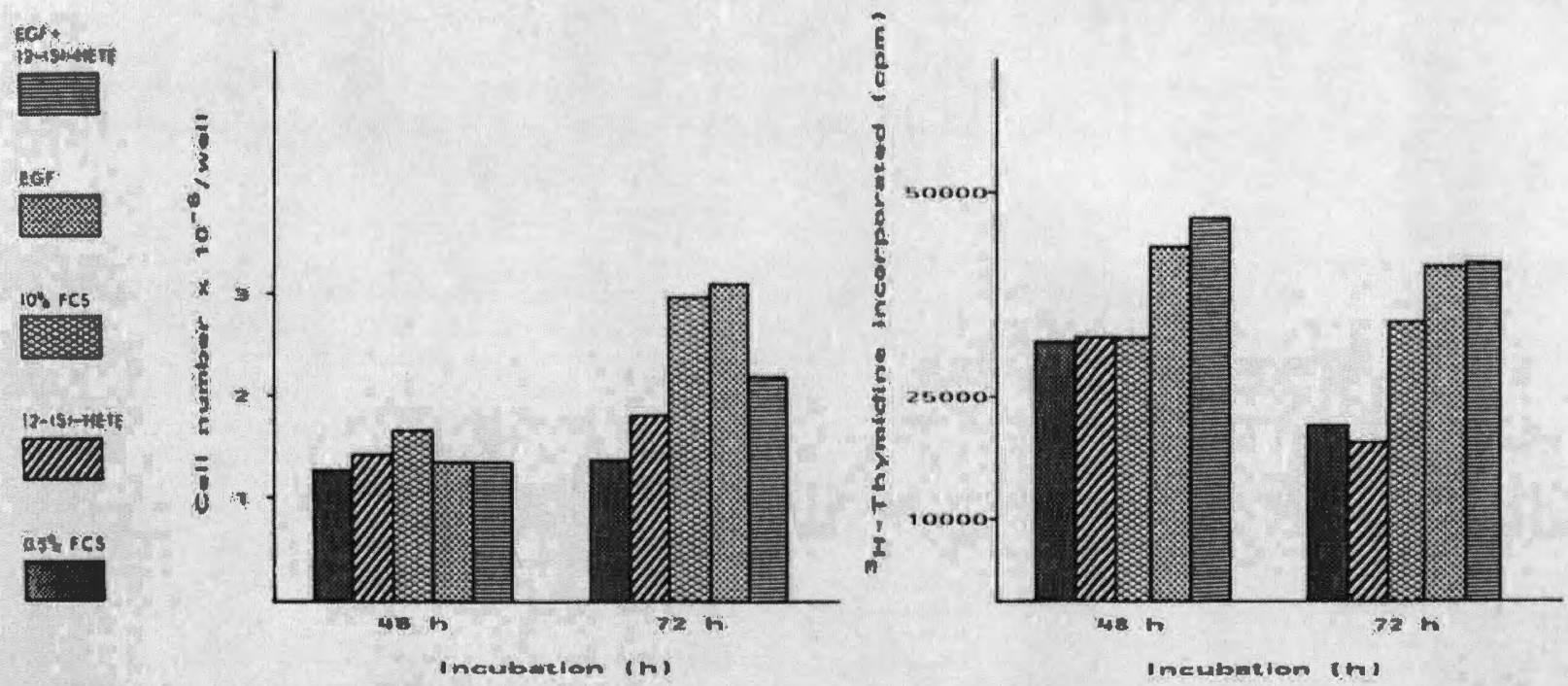

Figure s. influence of 12(S)-HETB on ${ }^{3} \mathrm{H}$-thymidine incorpacation and cell namber in SCL-II cells. The left pand shows cell numbers after 48 and $72 \mathrm{~h}$ of incubation with $12(5)$-HETE or controls. The right panel shows ${ }^{3} \mathrm{H}$-chymidine incorporation (cpm/well) after 48 and 72 h of incubation with 12(5)-HETE or controls. Date represent duplicate values. Similar results were obtained in four other experiments. 


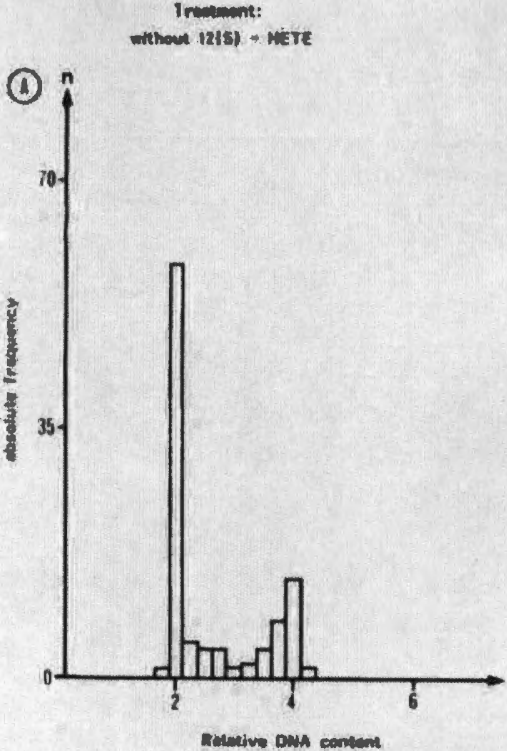

A

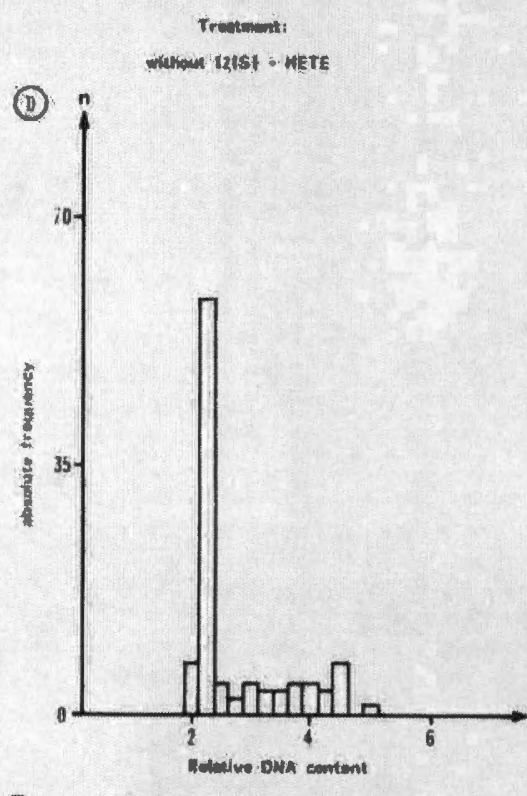

D

Pigure 6. Characteristic pattern of DNA histograms. Feulgen-stained SCL-II cells were analyzed by the image analysis syatem IPS. The relative DNA content of 100 randomly selected cells was measured. The mean value of the relative DNA content was used as marker for the prolifenative activity. A-C Relative DNA content after $24 \mathrm{~h}$ of treatment with 12(S)-HETE or controls. Mean walues of relative DNA content: $A, x=2.56 ; B, x=2.27 ; C, x=2.99$. $D-F$ Relative DNA content after $48 \mathrm{~h}$ of treatment with 12(S)-HETE or controls. Mean values of relative DNA content: $D, x=2.70 ; E, x=2.82 ; F$, $x-3.13$.

\section{REFERENCES}

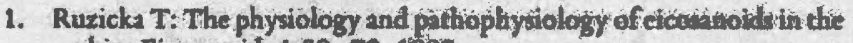
Atin. Eicosenoids 1:59-72, 1988

2. Greaves MW, Camp RDR: Prostaglandins, leukotrienes, phospholipases, platelet setivating factor, and cytokines: an integrated approach to inflammation of human skin. Arch Dermatol Res 280(suppl):33-41, 1988

3. Hammaratrom S, Lind gaen JA, Marcello C, Duell EA, Anderson TE, Voorhees II: Arachidonic acid transformations in normal and psoriatic stin. J Invest Dermatol 73:180-183, 1979

4. Ruxicke T, Printz MP: Artehidonic acid metabolion in guinea pig stin. Biochim Biophys Acts 711:391-397, 1982

5. Hammarström S, Hamberg M, Samuelsson B, Duell EA, Seawiski M, Voorhees ]J: Increased concentrations of non-esterified arachidonic

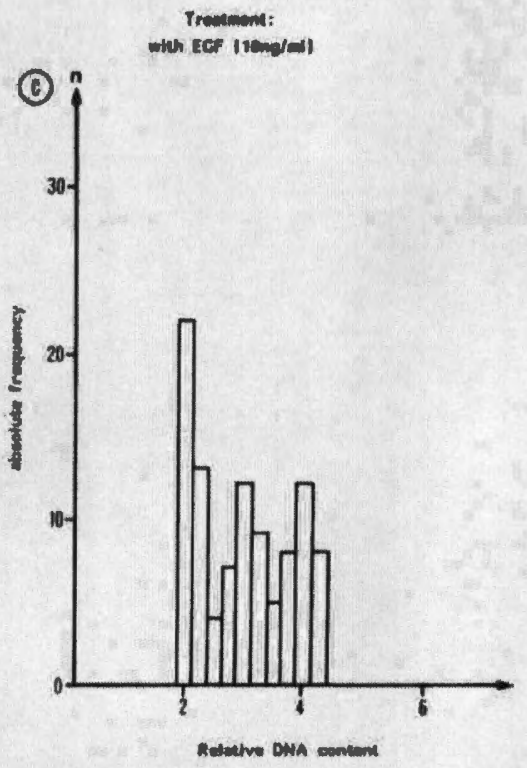

C

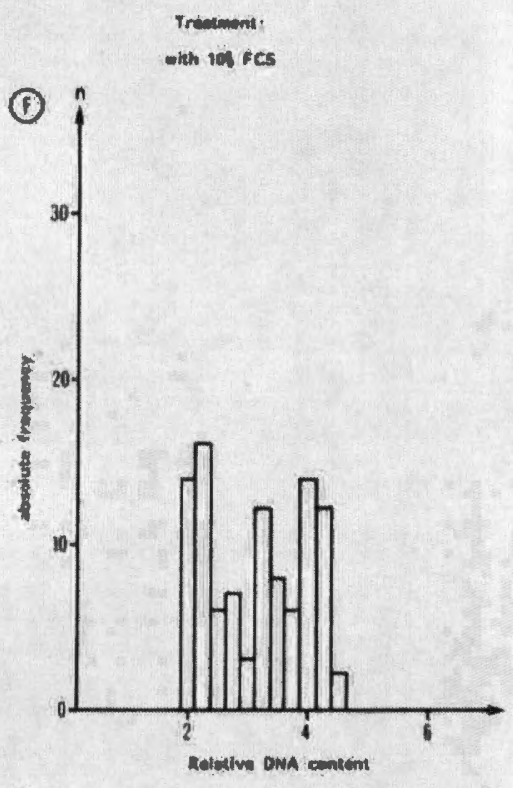

$\mathbf{F}$ 
9. Chen CC, Duhamel L, Ford-Hutchinson A: Leukouriene B, and 12 hydroxyeicosaterseenoic acid stimulate epidermal proliferation in vivo in the grinea pig. J Invest Dermatol 85:333 - 334, 1985

10. Rurzicka T, Burg G: Effects of chronic intracutaneous administration of arechidoric acid and its metabolites. Induction of leukocytoclattic vaseulitis by leukotriene $\mathrm{B}_{\text {, }}$ and 12-hydroxyeicosatetraenoic acid and its prevention by prostaglandin $\mathrm{E}_{2}$.J Inveat Dermatol 88:120 123,1987

11. Kregbille $\mathrm{K}$. Fallon jD: Increased aggregation and arachidonic acid transformation by psoriatic platelets: evidence that platelet-derived 12-hydroxyeicosatetraenoic acid increaves keratinocyte DNA synthesis in vitro. Arch Dermatol Res 278:449-453, 1986

12. Otzo WR, Barr RM, Dowd PM, Wright NA, Greaves MW: 12-hydroxy-5, 8, 10, 14-eicoantetraenoic acid (12-HETE) does not stimulate proliferation of human neonacal ketatinocyten. J Inveat Dermatol 92:683-688, 1989

13. Boukamp P, Rupnist TR, Fucenig NE: Baviroamental modulation of the expression of differentiation and malignancy in six human squamous cell carcinoma cell lines. Cancer Res 45:5582-5592, 1985

14. Chen RT: In situ detection of myocoplasma contamination in cell cultures by ffuoreseent Hoechst 33258 smin. Exp Cell Res 104:255-262, 1977

15. De Lean A, Hancock AA, Lefkowicz RJ: Validation and statistical analyais of a compater modeling method for quemsintive analynis of sadioligand binding date for mixtures of phimacological receptor subtypes. Mol Pharmacol 21:5-16, 1987

16. Klors XN, Lohse MJ, Schwabe U: Chemieal modification of $\Lambda_{1}$ adenosine receptors in me brain membeanet. J Biol Chem 263:17522 17526,1988

17. Böhn N: Einfluß der Fixierung and der Sxurenkonzentration auf die Feulgenhydrolywe bei $28^{\circ} \mathrm{C}$. Histochemie $142201-211,1968$

18. Bibbo M, Bartels PH, Dytch HE, Wied GL: Ploidy mearurements by high retalution cytometry. Anal Quane Cycol Histol 7:81 -87, 1985

19. Bocking $\mathrm{A}$, Adler CP, Common HH, Hilgart M, Granzen B, Auffetmann W: Algorithm for a DNA-cytophotometric diagnosis and grading of malignancy. Anal Quant Cyto 6:1 -8, 1984

20. Gross E, Ruricka T, Maucb C, Krieg T: Evidence for LTB 4 / 12-HETE binding sites in a human epidermal cell line. Proutaglandins 36:4958,1988

21. Wollard, PM: Stereochemical difference between 12 -hydroxy- 5,8 , 10, 14 -eicosatetreenoic acid in plateletes and peoriatic lesions. Biochem Biophys Res Commun 136:169-176, 1986

22. Schware PM, Kugelmumn LC, Coifman Y, Hough LM, Milstone LM: Human keratinocytes catabolize thymidine. J Invest Dermatol $90: 8-12,1988$

\section{THE SOCIETY FOR PEDIATRIC DERMATOLOGY}

\section{Research Grant}

The Society for Pediatric Dermatology announces a call for proposals to compete for a $\$ 5,000-\$ 10,000$ grant for scholarly clinical or basic research in the field of pediatric dermatology. Applications must be received by May 1, 1990. The 2ward will be announced on June 15, 1990. For further information and application forms, please address inquiries to the address listed below.

\section{Reeident's Award}

The Society for Pediatric Dermatology announces a call for papers by May 1, 1990 to compete for an annual award given to a pediatric or dermatology resident. A scholarly manuscript reporting on resules of a clinical or laboratory research project relating to pediatric dermatology will be chosen for presentation at the annual meeting of the Society for Pediatric Dermatology to be held this year in San Diego, California on August 8-11, 1990. The chosen resident will receive $\$ 500$ honorarium and expenses for two people to attend this meeting and present the paper. Manuscripts should be submitted to Anne W. Lucky, M.D., Chairman, Committee on A wards and Goals, Society for Pediatric Dermatology, c/o Dermatology Associates of Cincinnati, Inc., 7691 Five Mile Road, Cincinnati, Ohio 45230. 